\title{
Correlation between Cognitive Function and Physical Performance in Community-Dwelling Older Adults
}

\author{
Amanda Risviandari, ${ }^{1}$ Rensa $^{2}$ \\ ${ }^{1}$ School of Medicine and Health Sciences Atma Jaya Catholic University of Indonesia, Indonesia, \\ ${ }^{2}$ Department of Internal Medicine School of Medicine and Health Sciences Atma Jaya Catholic \\ University of Indonesia, Indonesia
}

\begin{abstract}
Background: One of the health problems often found among older adults in Indonesia is cognitive impairment, resulting in difficulties daily life and a significant decrease in functional status. This study aimed to determine the correlation between cognitive function and physical performance in community-dwelling older adults.

Methods: This was a cross-sectional study conducted from October-November 2019. Samples were collected from North Jakarta through consecutive sampling $(n=38)$. Cognitive function was measured using the Mini-Mental State Examination (MMSE) and the physical performance was measured using the Timed Up and Go Test (TUG) method. The statistical test applied in this study was Spearman's rank correlation $(\mathrm{p}<0.05)$.

Results: The majority of the subjects in this study were mostly female young older adults with the most received $\geq 12$ years of education. The results for both MMSE and TUG were normal. There was a negative correlation between MMSE and TUG scores ( $\mathrm{r}=-0.357, \mathrm{p}=0.028)$.

Conclusions: There is a weak but significant correlation between cognitive function and physical performance in community-dwelling older adults. A further study exploring cognitive dysfunction and physical performance in older adults is needed.
\end{abstract}

Keywords: Cognitive function, elderly, physical performance

\section{Introduction}

The older adult is those who have reached the age of 60 years or older. ${ }^{1}$ The proportion of the elderly population over 60 in Indonesia exceeds $7 \%$ of the total population, hence Indonesia is transitioning towards an aging population. $^{2}$ The number of older adults in Indonesia in 2019 was 25.9 million (9.7\%) and is expected to continue to increase to 48.2 million in $2035 .^{2}$ One of the health problems commonly found in an older adultis an impaired cognitive function. This cognitive impairment is in the form of difficulty remembering, recognizing, and thinking, affecting everyday life. ${ }^{3}$ The prevalence of people with cognitive impairments in Indonesia is about 2.2 million of total of 220 million people. ${ }^{4}$

Older adults with cognitive impairment will undoubtedly find it difficult to carry out daily activities. Thus, it can cause a significant decrease in functional status. ${ }^{5}$ The ability of an individual to carry out daily activities is determined by an understanding of physical performance. $^{6}$ Several components of a cognitive function affect a person's physical performance, including attention and executive function. Attention is the ability to focus on a specific stimulus, whereas executive function is the ability to perform complex motor functions. ${ }^{7}$ If these two components decrease in function, it may cause a mobility impairment in older adults. ${ }^{8}$ Older adults with low mobility will have a poor quality of life, encounter social isolation, and also become dependent on others' help because they cannot do it independently. ${ }^{9}$

This study aimed to determine the correlation between cognitive function and physical performance in community-dwelling older adults. By understanding the correlation, the number of older adults who experience

Correspondence: Amanda Risviandari, School of Medicine and Health Sciences Atma Jaya Catholic University of Indonesia, Jalan Pluit Raya No.2, Penjaringan, Jakarta Utara, Indonesia, Email: amandarsvdr@gmail.com 
physical performance impairment due to cognitive function impairment can be reduced.

\section{Methods}

This study was conducted from October to November 2019 with a cross-sectional study design. The study protocol had been approved by the Ethical Committee of School of Medicine and Health Sciences Atma Jaya Catholic University of Indonesia no. 33/11/ KEP-FKUAJ/2019. Samples were collected from the Santo Lukas Sunter Catholic Church, North Jakarta, DKI Jakarta through consecutive sampling. This place had a community of older adults who were active in carrying out daily activities. The number of samples needed was calculated by the sample size formula used for correlative analytical research. Respondents were approached and being informed about the study, and those who consented were then evaluated for eligibility. ${ }^{10}$ The inclusion criteria were those aged $\geq 60$ years old that were still able to walk, either with or without aid tools (canes, walkers), and who were willing to participate after giving consent. The exclusion criteria were those who had a habit of consuming alcohol, had experienced acute illness (respiratory infections, arthritis, and others), and had a history of orthostatic hypotension, hemiparesis, fractures, or illiteracy.

Cognitive function was measured using the Mini-Mental State Examination (MMSE) questionnaire, which contains five cognitive domains (orientation, registration, attention and calculation, recall, and language $)^{11}$ and was obtained through interviews. The cut-off point for the MMSE score based on education level was 22 for the 1-5 years of education, 23 for the 6-11 years of education, and 24 for the $\geq 12$ years of education. ${ }^{12}$ Physical performance was measured using the Timed Up and Go Test (TUG) method and a stopwatch was used to measure the time. The score was normal if $<10$ seconds, moderate impairment if 10-20 seconds, and severe impairment if $>20$ seconds. ${ }^{13}$ Spearman's rank correlation test was used as the statistical test considering the data to be tested was in the data was a categorical scale.

\section{Results}

In total, 38 older adults were participated, predominantly $(n=28)$ those in the young-old category of 60-69 years. The respondents were mostly females (34 of 38), and the highest education level was $\geq 12$ years ( 29 of 38 ). Since the respondents were limited, the frequency in percentage was not calculated. The MMSE and TUG results were mostly normal, with a median score of MMSE was 28 and TUG was 7.35 seconds as shown in Table 1.

Based on the age category in this study, those in the middle old category (70-79 years old) had more impaired cognitive function and moderate impairment of physical performance as depicted in Table 2.

The normality test was performed using the Shapiro-Wilk test, showing that the data distribution for the variable MMSE score

Table 1 General Characteristics of Respondents $(n=38)$

\begin{tabular}{lcc}
\hline \multicolumn{1}{c}{ Characteristics } & Mean (SD) or Median (Min-Max) & N \\
\hline Age (years) & $65.89(5.402)$ & \\
Young Old (60-69) & & 28 \\
Middle Old (70-79) & & 10 \\
Gender & & 4 \\
Male & $12.26(2.648)$ & 34 \\
$\quad$ Female & & \\
Education (years) & $28(18-30)$ & 9 \\
6-11 & & 29 \\
$\geq 12$ & & 29 \\
Cognitive Function & & 9 \\
$\quad$ Normal & & \\
Impaired & & 31 \\
Physical Performance (TUG Score) & & 7 \\
$\quad$ Normal (<10) & & \\
$\quad$ Moderate Impairment ( $\geq 10)$ & & \\
\hline
\end{tabular}

Note: TUG= Timed Up and Go Test; $\mathrm{SD}=$ standard deviation 
Table 2 Cognitive Function and Physical Performance based on Age Category

\begin{tabular}{lcc}
\hline & $\begin{array}{c}\text { Young old } \\
\mathbf{6 0 - 6 9} \text { years old })\end{array}$ & $\begin{array}{c}\text { Middle 0ld } \\
\mathbf{( 7 0 - 7 9} \text { years old })\end{array}$ \\
\hline Cognitive Function & & 3 \\
$\quad$ Normal & 26 & 7 \\
$\quad$ Impaired & 2 & 4 \\
Physical Performance & 27 & 6 \\
$\quad$ Normal & 1 & \\
$\quad$ Moderate Impaired & &
\end{tabular}

Note: TUG= Timed Up and Go Test; $\mathrm{SD}=$ standard deviation

Table 2 Cognitive Function and Physical Performance based on Age Category

\begin{tabular}{lccc}
\hline \multirow{2}{*}{ Cognitive Function } & \multicolumn{2}{c}{ Physical Performance (TUG Score) } & \multirow{2}{*}{$\mathbf{p}$} \\
\cline { 2 - 3 } & $\begin{array}{c}\text { Normal } \\
(<\mathbf{1 0})\end{array}$ & $\begin{array}{c}\text { Moderate Impairment } \\
(\mathbf{\geq 1 0})\end{array}$ & \\
\hline Normal & 26 & 3 & 0.028 \\
Impaired & 5 & 4 & \\
\hline Nonn & & &
\end{tabular}

Note: TUG= Timed Up and Go Test;

and TUG score was not normal $(\mathrm{p}=0.000$; $\alpha=0.05 ; p<\alpha)$. Furthermore, there was a weak and negative correlation between cognitive function and physical performance $(\mathrm{r}=-0.357)$. The correlation between cognitive function and physical performance in communitydwelling older adults was shown in Table 3.

\section{Discussions}

This study describes community-dwelling older adults who are mostly females and in young-old category (60-69 years old). In general, the status of cognitive function and physical performance of these elderly are normal. Furthermore, the middle old category (70-79 years old) has more impaired cognitive function as well as a moderate impairment of physical performance. Our study has shown a significant correlation between cognitive function and physical performance.

Cognitive impairment begins at the age of 50 , and it gets more severe at the age of $\geq 70$. Each component of cognitive function starts declining at a different age. For example, intellectual ability begins to decline at the age of 80 and executive function declines at age 70. Interestingly, attention begins to decline at the age of 20 , and visuospatial declines at age 60. Cognitive function impairment occurs as a result of the aging process, of which brain structure in the frontal cortex has significantly changed. There is a decrease in the volume of the gray matter and the white matter. By the age of 70 , the gray matter decreases by
$6.14 \%$, while the white matter decreases by $16-20 \% .^{14}$

This study has shown that an increase in the MMSE score correlates with the decrease of the TUG score. The higher MMSE score means better cognitive function; whereas the lower TUG score means better physical performance. Prior research showed that $11.3 \%$ of the elderly aged 45 to 64 years and $31.7 \%$ of the elderly aged $\geq 65$ years experience difficulty in moving. ${ }^{15}$ The decline in physical performance among older adults can be caused by decreased muscle mass and muscle strength with age, which begins at 50 years. ${ }^{16}$ Furthermore, there is a strong and negative correlation between dementia and functional ability. It also shows that the MMSE score is dominated by mild cognitive impairment $(56.25 \%) .{ }^{17}$ A study among older adults aged 69-80 years in Malaysia also shows that there is a weak and negative correlation between cognitive function and physical performance. ${ }^{18}$ The cognitive abilities will decrease as aging occurs, so that the ability to learn new things, carry out orders, and good coordination between understanding, attention, and a person's motor skills to perform activities are also declined.?

There are several limitations in this study, one of which is the possibility that some of the information given during the interview is not easily understood by the elderly. The design of this study, which is cross-sectional, can only show things that are happening at present moment, thus, any clausal relation cannot 
be described. The respondents in this study are limited, thus further study is interesting to explore this correlation in broader multi variables.

In conclusion, there is a statistically significant correlation, hence a weak and negative correlation, between cognitive function and physical performance in community-dwelling older adults. Further study is imperative, to prevent an increasing number of cognitive impairment and physical performance impairment in older adults.

\section{References}

1. Jaul E, Barron J. Age-related diseases and clinical and public health implications for the 85 years old and over population. Front Public Health. 2017;5:335.

2. Soulissa AG. A review of the factors associated with periodontal disease in the elderly. Journal of Indonesian Dental Association. 2020;3(1):47-53.

3. Dini AA. Sindrom geriatri (imobilitas, instabilitas, gangguan intelektual, inkontinensia, infeksi, malnutrisi, gangguan pendengaran). Medula. 2013;1(3):117-25.

4. Sengkey AH, Mulyadi M, Bawotong J. Hubungan depresi dengan interaksi sosial lanjut usia di desa tombasian atas kecamatan kawangkoan barat. E-Journal Keperawatan. 2017;5(1):15948.

5. Mongisidi R, Tumewah R, Kembuan MAHN. Profil penurunan fungsi kognitif pada lansia di Yayasan-yayasan manula di Kecamatan Kawangkoan. Jurnal e-CliniC. 2013;1(1):1-10.

6. Van Lummel RC, Walgaard S, Pijnappels M, Elders PJM, Garcia-Aymerich J, Van Dieën $\mathrm{JH}$, et al. Physical performance and physical activity in older adults: associated but separate domains of physical function in old age. PLoS One. 2015;10(12):e0144048.

7. Harada CN, Natelson Love MC, Triebel KL. Normal cognitive aging. Clin Geriatr Med. 2013;29(4):737-52.

8. Ferrucci L, Cooper R, Shardell M, Simonsick EM, Schrack JA, Kuh D. Age-related change in mobility: perspectives from life course epidemiology and geroscience. J Gerontol
A Biol Sci Med Sci. 2016;71(9):1184-94.

9. Manini TM. Mobility decline in old age: a time to intervene. Exerc Sport Sci Rev. 2013;41(1):2.

10. Setia MS. Methodology series module 5: sampling strategies. Indian $\mathrm{J}$ Dermatol. 2016;61(5):505-9.

11. Prakoso K, Vitriana, Ong A. Correlation between cognitive functions and activity of daily living among post-stroke patients. Althea Medical Journal. 2016;3(3):329-33.

12. Kochhann R, Varela JS, de Macedo Lisboa CS, Chaves MLF. The mini mental state examination: review of cut off points adjusted for schooling in a large Southern Brazilian sample. Dement Neuropsychol. 2010;4(1):35-41.

13. Nurmalasari M, Widajanti N, Dharmanta RS. Hubungan riwayat jatuh dan timed up and go test pada pasien geriatri. Jurnal Penyakit Dalam Indonesia. 2018;5(4):1648.

14. Laksmidewi AAAP. Cognitive changes associated with normal aging. In: Laksmidewi AAAP, Adnyana IMO, Meidiary AAA, Susilawathi NM, Witari NP, Yuliani $D$, et al., editors. Proceeding the $4^{\text {th }}$ Bali Neurology Update; 2016 July 22-24. Denpasar: Udayana University Press; 2016.

15. Satariano WA, Guralnik JM, Jackson RJ, Marottoli RA, Phelan EA, Prohaska TR. Mobility and aging: new directions for public health action. Am J Public Health. 2012;102(8):1508-15.

16. Norheim KL, Hjort Bønløkke J, Samani $A$, Omland $\varnothing$, Madeleine P. The effect of aging on physical performance among elderly manual workers: protocol of a cross-sectional study. JMIR Res Protoc. 2017;6(11):e226.

17. Suwarni S, Setiawan S, Syatibi MM. Hubungan usia demensia dan kemampuan fungsional pada lansia. Jurnal Keterapian Fis. 2017;2(1):34-41.

18. Won H, Singh DKA, Che Din N, Badrasawi M, Manaf ZA, Tan ST, et al. Relationship between physical performance and cognitive performance measures among community-dwelling older adults. Clin Epidemiol. 2014;6:343-50. 